University of Nebraska - Lincoln

DigitalCommons@University of Nebraska - Lincoln

Faculty Publications: Department of Teaching, Department of Teaching, Learning and Teacher Learning and Teacher Education

Education

September 2007

\title{
Language: Use By Women: North America: Yemeni American Girls
}

Loukia K. Sarroub

University of Nebraska-Lincoln, Isarroub@unl.edu

Follow this and additional works at: https://digitalcommons.unl.edu/teachlearnfacpub

Part of the Teacher Education and Professional Development Commons

Sarroub, Loukia K., "Language: Use By Women: North America: Yemeni American Girls" (2007). Faculty Publications: Department of Teaching, Learning and Teacher Education. 28.

https://digitalcommons.unl.edu/teachlearnfacpub/28

This Article is brought to you for free and open access by the Department of Teaching, Learning and Teacher Education at DigitalCommons@University of Nebraska - Lincoln. It has been accepted for inclusion in Faculty Publications: Department of Teaching, Learning and Teacher Education by an authorized administrator of DigitalCommons@University of Nebraska - Lincoln. 
Published in Encyclopedia of Women \& Islamic Cultures, Volume V: Practices, Interpretations and Representations. General Editor: Suad Joseph; Associate Editors: Afsaneh Najmabadi, Julie Peteet, Seteney Shami, Jacqueline Siapno, \& Jane I. Smith; Assistant Editor: Alice Horner. Brill: Leiden \& Boston, 2007. Pp. 237-240.

Copyright (C) 2007 by Koninklijke Brill NV, Leiden, The Netherlands. Used by permission.

\title{
LANGUAGE: Use By WoMen
}

\section{North America: Yemeni American Girls}

\author{
Loukia K. Sarroub \\ University of Nebraska-Lincoln
}

Yemeni migration to the United States is part of a larger historical trend of Arab immigration to North America. Many recent immigrants moved to the Detroit area because they could find work in the shipping and auto industries, and since the 1970s, southeastern Michigan has had the highest concentration of Arabicspeaking people outside the Middle East, an estimated 250,000 residents (Ameri and Ramey 2000, Zogby 1995). Unlike earlier Arab immigrants, recent arrivals from northern Yemen have persisted in preserving both their Muslim ways of life and their Arab identities. These immigrants have kept strong ties with their motherland, buying land in Yemen with the intention of going back, visiting for long periods, and sending their children there to marry. Consequently, in the United States, the children of these immigrants straddle two worlds, the literate world of school and the home world of religious and cultural values where the text of the Qur'ān sanctions behavior and social norms.

This entry focuses on Yemeni American high school girls or hijābāt (what the girls call themselves, girls who wear the headscarf) in the Detroit working-class suburb of Dearborn. While their experiences are unique, they are also instructive in understanding the roles of religious oral and print texts among other Muslim women immigrants - and their daughters - in contemporary North America.

The Yemeni community of Dearborn, Michigan lives in a neighborhood called "the Southend" where they have formed their own social and linguistic spaces. Girls leave the Southend only to go to school or during family outings. Living in two worlds can be difficult for all of the residents, but especially for young women who struggle to negotiate their Yemeni and American identi- 
ties as well as to meet their families' expectations for being good daughters. Their responsibilities are three-fold: to uphold the transnational honor of the family; to become good mothers (most are engaged or married by the age of 14 or 15); and to succeed in school. In their daily efforts to meet these responsibilities, Yemeni hijābāt rely not only upon a variety of religious texts but also on the process of discussing these texts with their peers in school, home, and community spaces.

\section{Religiously motivated teXtUAL CATEGories}

The public high school is a key cultural intersection and is where Yemeni American girls adapt to American life by organizing behaviors into three categories which stem from the Qur'ān and religious teachings: haram, forbidden; halāl, lawful; and makrūh, not written as forbidden in the Qur'an but condemned by the Prophet Muhammad. All things haram are written in the Qur'ān, such as drinking alcohol. Things halāl are good deeds, which include learning and being learned. Things makrūh include wearing make-up before marriage or listening to music. Indeed, many of the hijābāt wore nail polish or eyeliner and listened to popular music even though the Prophet forbade it. However, because nothing is written in the Qur'ān about such things, Islamic scholars and ordinary Muslims debate these issues constantly. At school, the hijābāt used the terms haram and halāl liberally, especially when a girl's modesty was in question. The students argued about what was haram when something was called into question, and advice was often sought from peers who were respected for their knowledge of the Qurān and the hadith (recorded words, actions, sanctions of the Prophet Muhammad). Girls who were pious or wanted to appear pious did not do or say anything that was likely to be considered makrūh. In fact, except for some girls who studied and read the Qur'ān, the category makrūh was not known or well understood by most girls and boys. For the hijābāt, most of life fell under haram or halāl, and when scripture did not provide an answer, there was always what they called the Yemeni "folk Islam," that is, occult beliefs or superstitions that helped explain and remedy problems.
Arranging life into religiously motivated textual categories gave the hijābāt the opportunity to maintain Yemeni social status and norms within the confines of school. Yet, school also gave the girls the chance to stretch home and community-imposed limits. For example, unlike most teenagers, the hijāa àt were often not allowed to listen to American popular music, which was in the makrūh category, and they were also not allowed to read teen magazines, or anything that might be sexually explicit or imply sexuality. At school they created a private space for themselves in their cafeteria cluster of tables, buffered by the non-Arab students against the Yemeni boys, whom they called "boaters," and who would often report back to the Southend on the hijāba at if they did not maintain a proper social performance of modesty, thus damaging the hijābāt's reputations. Here the girls brought forth their contraband: teen magazines, yearbook pictures which could only be seen by them, and fable-like poems and stories, especially about girls who misbehaved. They gossiped around these texts, sharing personal information about their marriages, their families, and the men they would like to marry (often in opposition to the ones to whom they were betrothed). During one such instance, there was extensive discussion of Princess by Jean Sasson, a popular biography about the tragedies experienced by a Saudi Arabian princess who managed to escape her family and country. This was not a book they openly discussed or read at home because, as one noted, "It makes Islam and Muslims look bad." They argued that Princess Sultana's narrative by Sasson is a story about culture and not about religion, an important distinction for these girls because it meant that while their religion and their Holy Book could not be questioned, their culture and cultural acts could. Thus, when the hijāba ât were upset with family decisions about education or marriage, they were very careful to blame it on Yemeni culture and not on Islam.

The significance of the relatively safe crowded cafeteria is that it offered a haven for sharing secret texts, including texts that were American and that represented American values that differed from Yemeni ones. For example, a poem written in English was downloaded from the Internet and was passed among the girls. It was about a girl who goes out with a boy even though 
her parents do not allow her to date. The boy drinks heavily and crashes his car into another. At the hospital, the girl asks the nurse to tell her parents that she is sorry. The nurse does not say anything as the girl dies. It turns out that the car into which the girl and her boyfriend crashed was occupied by her parents, who were both killed instantly. The girls reacted to this poem with loud exclamations of "Haram!" and said that although they admired the girl for taking a risk, that disobeying and hurting one's parents through one's actions is forbidden.

\section{RELIGIOUS INSTRUCTION AND PRACTICES}

Daily reading of the Qur'ān was as symbolically important in the hijābāt's lives as their modest form of dress. Reading the Quraan led to three distinct results: being more knowledgeable about the contents of the Qur'ān and therefore more respected by one's family and community; reaching a state of grace by virtue of the fact that reading it endows a spirituality or holiness; and empowering oneself against culturally-biased acts against Muslims. In fact, parents took pride in the fact that their sons and daughters, but especially their daughters, read the Qur'ān and prayed. At a parents' school meeting about school violence, one father praised his son's high grades but chose to describe his daughter's success at being a result of prayer, noting, "She prays more than I do." In other words, although most of the Yemeni families desired both their male and female children to know the Qur'ān and to pray, these characteristics were especially valued in girls because they reflected the family's honor. It was the girls' responsibility to maintain religious values, thus reinforcing a gendered notion of religion. The girls knew this and were genuinely involved in their religious practice, but they were also cognizant of the power to be assumed through thorough knowledge of the Qur'ān. Consequently, the hijābāt also attended Arabic school at the mosque, classes that were gender segregated, included grades $\mathrm{K}-7$, and met at weekends from 8:30 A.M. until noon for instruction, after which lectures were scheduled. All of the instruction revolved around reading, writing, and the Qur'àn. The oral and written texts with which the hijāba àt engaged allowed them to connect their religious practice to their identities as teenagers, but they also positioned them as pious girls for whom reading the Qur'ān and chanting verses presented an antidote to the influences of the outside world.

Some girls also attended muhâa darāt (lectures, and discussions organized by women in the community that took place either at the mosque or in a private home. The muhạdarāt at the mosque were talks where a woman speaker addressed women's issues in front of an audience with discussion at the end but those held in someone's home were different, more private and informal. The hijāba $\bar{t}$ noted that they could talk to the woman who was hosting the lecture and respected her because, unlike many of the women in the local community, she could read and write in Arabic and recite the entire Qur'ān. She had achieved the state of grace and power into which the girls wanted to enter. After the evening prayer, each of the women brought something specific to read from the Qur'àn or from a book on Muslim religious conduct; this was followed by a lecture on morality. The conversations during muhâa darāt were characterized by the girls as more intellectual and religious and they saw the reading of the Qurān and the conversation which ensued around the readings as knowledge to be learned rather than just talk among friends or "stuff you learn at school." These groups of girls grappled with religious and moral issues for a purpose: to stay pure and true to Islam, to show their community that they were good Muslim girls, and to vocalize potentially risky topics that they could not openly discuss in school or elsewhere. The Yemeni American hijābāt from the Southend shoulder a great deal of responsibility at a young age. They must excel in all domains of their lives - school, community, home, and housekeeping — in preparation for marriage, their adult roles, and the possibility of more education in university settings. For them, religious texts provide meaningful and relevant maps for navigating their complex personal, social, and cultural realities.

Note: Sections of this entry have been adapted from L. K. Sarroub 2001, 2002, and 2005. 


\section{BIBLIOGRAPHY}

A. Abraham and A. Shryock (eds.), Arab Detroit. From margin to mainstream, Detroit 2000.

S. Abraham, N. Abraham, and B. Aswad, The Southend. An Arab Muslim working-class community, in S. Abraham and N. Abraham (eds.), Arabs in the new world. Studies on Arab-American communities, Detroit 1983, 164-80.

A. Ameri and D. Ramey (eds.), Arab American encyclopedia, Detroit 2000.

V. Amit-Talai and H. Wulf (eds.), Youth cultures. A cross-cultural perspective, London 1995.

J. Boyarin, The ethnography of reading, Berkeley 1992.

D. Brandt, Literacy in American lives, New York 2001.

J. Friedlander, Sojourners and settlers. The Yemeni immigrant experience, Salt Lake City 1988.

K. Haw, Educating Muslim girls. Shifting discourses, Buckingham, England 1998.

A. Naff, Becoming American. The early Arab immigrant experience, Carbondale, Ill. 1985.
A. Portes and R. G. Rumbaut, Immigrant America. A portrait, rev. ed., Berkeley 2006.

C. Raissiguier, Becoming women, becoming workers. Identity in a French vocational school, Albany, N.Y. 1994.

L. K. Sarroub, The sojourner experience of Yemeni American high school students. An ethnographic portrait, in Harvard Educational Review 3 (2001), 390-415.

_- In-betweenness. Religion and conflicting visions of literacy, in Reading Research Quarterly 37:2 (2002), $130-48$.

—_, All American girls. Being Muslim in a public school, Philadelphia 2005.

S. Scribner, Literacy in three metaphors, in American Journal of Education 93:1 (1984), 6-21.

B. V. Street, Social literacies. Critical approaches to literacy in development, ethnography, and education, London 1995.

J. Zogby, Arab American demographics, Washington, D.C. 1995. 